\title{
My Men Have Become Women, and My Women Men: Gender, Identity, and Cursing in Mesopotamia
}

\author{
Gina Konstantopoulos
}

\begin{abstract}
The following essay considers the ways in which masculinity and femininity can be seen as potentially fluid, rather than rigid, categories in the ancient Near East, and furthermore understood as part of shifting nexus of power and agency - or lack thereof. Specifically gendered insults exploited the fluidity of these categories by focusing in particular on the forced emasculation and feminization of men in the ancient Near East, and these insults were often used as binding threats in treaty texts. Such punishments, as they invariably were, had close associations with the goddess Ištar, who was often responsible for acting as the agent of such enforced change. While the majority of these situations moved one from a position of greater to lesser agency and power (and thus from the masculine to feminine category), the opposite was possible in the ancient Near East. In limited and specific circumstances, women could also gain, in part, some of the agency that was normally reserved for men, a status that could be reflected in the ways in which they were indicated and referred to in texts.
\end{abstract}

\section{Introduction}

Gender in the ancient world is more fluid than it might first appear. It can shift and, in certain circumstances, it may even be weaponized, with threats of lost masculinity or enforced femininity levied against an opponent. Though this paper deals with such phenomena within Mesopotamia in particular, it is also observed within other ancient contexts, including, perhaps most famously, that of ancient Greece. Book eight of Herodotus's Histories recounts, among other events of the Greco-Persian wars, the naval battle of Salamis (480 BCE). ${ }^{1}$ In this climatic battle, Artemisia of Halicarnassus, the only woman among Xerxes' commanders, finds herself trapped, her ship penned in by an Athenian vessel. She rams the nearest available ship - one allied to Xerxes - and sinks it. She is rewarded twice-over for her decisive actions. The Athenian ship, seeing her attack a Persian vessel, takes her ship to be Greek and retreats from pursuit. Xerxes, upon being told of the events, assumes the ship Artemisia so courageously rammed and sunk was, of course, Greek, rather than an ally vessel. He manages to praise her and lament the sad state of his navy and its commanders in the same breath, bemoaning that: "My men have turned into women and

1 For this passage within the text, see Waterfield 1998. 


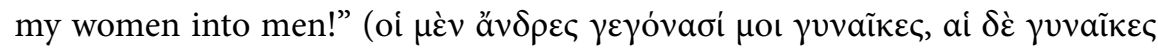
ä $v \delta \rho \varepsilon \varsigma)[8.88 .3] .{ }^{2}$

Artemisia is uniquely placed to incite such a comment from Xerxes, as she slides across gender divisions and categories. In her discussion of women in Herodotus, Josine Blok describes how Artemisia embodies duality: she is "both female and masculine, Greek and enemy, cunning and victorious," and represents the triumphant use and great rewards of intelligence and wit. ${ }^{3}$ Artemisia's capacities as an advisor, a function of her great intelligence and skill in military strategy, allow her to act within the otherwise entirely male world of military command. ${ }^{4}$ Although the Amazons had already provided a model for 'warrior women' in ancient Greece, they were a defined category onto themselves, and their strength cast them in a different light than Artemisia's appearances. Similar to Artemisia, however, the Amazons were also defined as foreign individuals from the point of view of the authors of the texts to feature them. ${ }^{5}$

Although the Sumerian and Akkadian texts of Mesopotamia are distinct from the texts of ancient Greece and the warrior women who populated them, they share a similar topography of gendered insults and curses, whereby a man's martial prowess or courage could be derogatorily compared to the skills of a woman. Such insults transgressed the rigidly established gender lines of Mesopotamian society, lines that were often clearly expressed in texts. Unsurprisingly, the vector or lynchpin for such insults was frequently Ištar, the goddess of love and war and a transgressive figure of the highest order. Ištar held a broad and multi-faceted position within Mesopotamian religion and society. ${ }^{6}$

The following essay has not one but three aims: first, to sketch out the general narrative of insults and imagery centered on the forced emasculation and subsequent feminization of men, often within a martial context, in the ancient Near East. Second, to examine the role that Ištar, as well as other liminal beings, played as the critical delivery mechanism for such threats. And third, to demonstrate that these insults are by no means localized to the ancient Near East, but similar concepts are enmeshed in the presentation of male and female as moveable constructs, which may be applied to praise or deride an individual of either gender.

2 Translation following Waterfield 1998: 516-517. As Bowie (2007: 179) notes in commentary on this passage: "the seriousness of this comment may be judged by Herodotus' remark that 'the greatest reproach amongst the Persians is to be called worse than a woman' (9.107; cf. 20).'

3 Blok 2002: 240-241.

4 Munson 1988: 94.

5 See Adrienne Mayor's (2014) overview on the Amazons, particularly her introduction to the different depictions of their homeland, a location that is principally described as Scythia, in texts (34-51).

6 On Ištar, see Pryke 2017. 


\section{2. 'Regardless of Sex:' Approaching Gender Anxiety}

The topic of sex and gender in the ancient Near East is a complicated one, and the full scope of it lies well beyond the boundaries of this article. In an article on gender and masculinity in Mesopotamia, Jerrold S. Cooper aptly and succinctly summarized the complex nature of the topic by stating that: "A discussion of masculinity in ancient Mesopotamia risks becoming very large indeed."7 Constructing masculinity (and inversely, femininity, either as an independent concept or a reactionary threat to or attack on masculinity) can only be achieved through analyzing a wide range of evidence; including, references to masculinity found in different textual genres; artistic representations of "the gendered body;" and nuanced terms used in different levels of cuneiform scholarship and commentary. ${ }^{9}$ I would also clarify that within the context of this article, I principally speak of gender rather than biological sex and of the actions and markers of masculinity as an active (and actively performed) enterprise. ${ }^{10}$

Given the presence of a large body of scholarly work regarding gender in Mesopotamia, it may seem at first surprising that I have chosen a comparative framework to discuss threats of lost masculinity or enforced femininity, and to this end will continually reference Carol Clover's study of similarly gendered phenomena and expressions within the context of medieval Icelandic sagas. However - perhaps because of the disconnect between her source material and that of Mesopotamia - this comparison proves a useful lens through which to view Mesopotamia's own weaponization of the shifting battle lines of gender categories. Clover introduces her article with a discussion of a gender-based insult levied within one text, the Gísla saga. ${ }^{11}$ The insult centers on the use of the terms blaudr and hvatr, words associated with feminine and masculine qualities, respectively. ${ }^{12}$ The former is most visibly applied not to describe women but

7 Cooper 2013: 113. See also the essays in the volume edited by Svärd and Grace-Ventura (2018), the collected publication of several conference and workshop meetings on the theme of gender in the ancient Near East.

8 See Asher-Greve 1997 for a discussion of textual as well as artistic representations (and divisions in classifying or categorizing) the gendered body.

9 We see, for example, not only a range of Sumerian language terms that may be used to describe the body, including: su, su-bar, ša ${ }_{3}$, and me- $\operatorname{dim}_{2}$ (Asher-Greve 1997: 433), but also the progression of masculinity as expressed in lexical lists, as in a section of Ugu-Mu (or, "My Skull"), which focuses on anatomical vocabulary (Westenholz and Zsolnay 2016: 26): my status as a

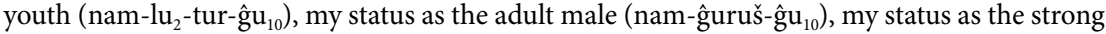
one (nam-kalag-ga-ĝ $\mathrm{gu}_{10}$ ), my status as the hero (nam-ur-saĝ-ĝ $\mathrm{u}_{10}$ ), my status as the old man/ elder (nam-ab-ba- $\hat{\mathrm{g}} \mathrm{u}_{10}$ ). On Ugu-Mu, see the recent study and overview in Couto-Ferreira 2017.

10 Such a distinction and definition leans heavily on the work of Judith Butler (1999). Butler describes gender as "in no way a stable identity or locus of agency from which various acts proceed; rather, it is an identity tenuously constituted in time - an identity instituted through a stylized repetition of acts" (1988: 519).

11 Clover 1993: 363-65. See further discussion of masculinity and femininity in Turco (2016: fn. 13), particularly the cited overview of previous literature on the subject of gender in the text.

12 Clover also presents a definition and discussion of these terms in her article (1993: 364). 
to insult men by comparing them to women, with apparently associated connotations of cowardice. The variable application of these terms, Clover states, underscores a fundamental disquiet in the Norse mind with regards to be gender and its categories in society:

What finally excites fear and loathing in the Norse mind is not femaleness per se, but the condition of powerlessness, the lack or loss of volition, with which femaleness is typically, but neither inevitably nor exclusively, associated. By the same token, what prompts admiration is not maleness per se, but sovereignty of the sort enjoyed mostly and typically and ideally, but not solely, by men. ${ }^{13}$

The qualification that maleness is not a categorization of gender as much as it is an expression of power and independent freedom is key. To be 'male' is have greater standing and personal sovereignty in society. Given the martial underpinning to Norse culture, as expressed through literature, myths, and epics, (a trait shared with Mesopotamia) such standing is often expressed through displays of physical force. ${ }^{14}$ If being a warrior is to demonstrate and hold power, then masculinity codes itself as a display of martial ability to reinforce its own power. This division does not preclude a woman from demonstrating an affinity for warrior abilities - and thus coding herself as masculine and moving away from feminine categorizations - and it also establishes a correspondence whereby losing martial ability is equivalent to losing one's masculinity. In her work, Clover expands on these shifting categories, through a discussion of gender theory that remains useful to the Mesopotamian model:

This is in any case not a world in which the sexes are opposite or antithetical ... On the contrary, it is a world in which gender, if we can even call it that, is neither coextensive with biological sex, despite its dependence on sexual imagery, nor a closed system, but a system based to an extraordinary extent on winnable and losable attributes. It goes without saying that the one-sex or single-standard system (in the sense I have outlined it here) is one that advantaged men. But it is at the same time a system in which being born female was not so damaging that it could not be offset by other factors. A woman may start with debits and a man with credits, but any number of other considerations - wealth, marital status, birth order, historical accident, popularity, a forceful personality, sheer ambition, and so on - could tip the balance in the other direction. ${ }^{15}$

This one-gendered system of 'debits and credits' as described above thus engenders a sense of paranoia within the masculine mind. If categories are not fixed, it is always possible to lose membership in the masculine category and along with it, the protections and privileges it provided. Similarly, women, though

13 Clover 1993: 379. This anxiety is also discussed in Sørensen 1983.

14 Chapman 2018: 20-59 discusses the role of masculinity in martial contexts as connected in particular Assyrian material.

15 Clover 1993: 379. 
overwhelmingly restricted to feminine designations, could also move into the male category. In Mesopotamia, as I shall discuss at the close of this article, such movements were extraordinary events - rarer, it seems, than within the Norse material, which enjoyed a long tradition of warrior women that is principally absent in Mesopotamian texts ${ }^{16}$ - but they did happen, most often thanks to the presence of family wealth coupled with extenuating circumstances, such as the absence of other male relatives.

The fear of falling away from the warrior category is expressed in Mesopotamian sources, in examples that make it clear belonging to this category is reliant on one's continued martial ability. In the first millennium BCE Akkadian literary epic Erra and Išum, the bellicose Sebettu, a group of seven divine/demonic figures, rail against their recent inactivity, despairing at how their skills in battle have grown rusty with lack of use. In a long speech to Erra, they chastise the god for his inaction and lack of active campaigning:

Erra and Išum, Tablet I, 47-50:

min-su ki-i ši-i-bi muq-qí tu-šib ina āli

$k i-i$ šèr-ri la-' $i$ '-i tu-šib ina bìtim

ki-i la a-lik EDEN ni-ik-ka-la a-kal sin-niš

ki-i šá ta-ha-zi la ni-du-ú ni-ip-la-ḩa ni-ru-da

Why have you been sitting in the city like a feeble old man,

[Why] sitting at home like a helpless child?

Like those who do not venture afar, shall we eat the bread of women?

As those who do not know battle, shall we be afraid and tremble? ${ }^{17}$

In this speech, the Sebettu extol the glory of the warrior's life, comparing war to a glorious festival. They state that one who does not fight and campaign will never measure up to a warrior: "However sturdy a civilian's muscles, how can he wax strong as a veteran soldier?"18 Beyond the glory of battle, the Sebettu's speech reveals the anxiety that underlies masculinity as presented in this text: if one is not able to campaign, which is to say, to act as an warrior, they risk being

16 I principally reference here the presence of arguably third-gendered figures in Norse texts, such as Valkyries and Shield-Maidens. Both figures represent and embody masculinity, participating in masculine activities, such as battle, and acting in masculine ways (Self 2014: 152-156). Unlike Valkyries, however, who remain able to operate in both masculine and, to a degree, feminine spheres, shield-maidens are only permitted to act in a masculine manner until they marry, at which point they give up their ability to perform within this sphere (Norrman 2000: 384). For discussions of warrior women in this and other contexts in Europe, see Clover 1986; McLaughlin 1990. Further overviews of women in Norse society are found in Jochens 1996: 87-112; Friðriksdóttir 2013; and Gardeła 2013, which focuses on the archaeological and funerary evidence for warrior women in Scandinavia during the Viking age.

17 Following edition in Cagni 1969.

18 Erra and Išum Tablet I: 55-56; see again Cagni 1969. I follow here the translation in George 2013: 52-53, who discusses the ramifications of this passage overall. 
re-classified and placed alongside categories that only include non-combatants: the old (whether men or women), children, and women of any age. Within the world of Erra and Išum, at the least, it is clearly possible for an able-bodied and martially capable man to fall into this less privileged category. ${ }^{19}$

\section{Threatening Masculinity in Texts}

The trope of equating masculinity with warrior qualities and martial prowess is broadly represented throughout the ancient Near East. Arising from the ubiquity of this imagery, we see the emergence, primarily in the latter half of the second millennium BCE, of a specific type of insults and curses, whereby men, particularly in a martial context, are threatened with the removal of their masculine (namely warrior) abilities and the imposition of enforced femininity. Their weapons are taken from them, and they are rendered powerless and equated directly to women. These threats have been discussed in previous scholarship, but I will present them in brief in this section, placed within the methodological framework of studying gender already introduced in this study. ${ }^{20}$

Within royal inscriptions, this imagery is seen in texts connected to several different kings. The earliest belongs to Tukulti-Ninurta I, detailing his military exploits and the construction of a new palace at Aššur. The close of the inscription states the fate of his enemy, and how Ištar: "... may she change him from a man to a woman (zikrūssu sinnisāniš), may she cause his manhood to dwindle away."21 Though the inscriptions has no explicit mention of Ištar divesting the man of his weapons, the punishment inherent in the replacement of his masculinity with femininity is clear.

While most references to enforced femininity belong to the first millennium, rather than the second, the above text from Tukultī-Ninurta I is joined chronologically, if not preceded, by those found in Hittite prayers and military oaths. Both are far more explicit examples of this trope, specifically citing how the oath-breaker shall be divested of his weapons and changed into a woman. The first, a prayer and ritual invoking Ištar, describes how the goddess shall "grind away from men manliness," destroy their potency, presumably sexual, and their overall health, before continuing to describe how she shall:

19 The Akkadian word for the adjective feeble, muqqu, is generally used in conjunction or parallel with the elderly (šibu); CAD M2.

20 For a discussion of these threats, see Bergmann 2008: 134-137 and Zsolnay 2010: 394-400.

21 Grayson 1987: 238 (Tukulti-Ninurta I A.0.78.1: vi 13-17). As Zsolnay 2010 discusses, there is considerable debate over the exact translation of this passage. I follow here Grayson's translation, but other possibilities provide different, if subtle, interpretations of the line, particularly governing "may she change him from a man to a woman." 
Take away their swords, bows, arrows, daggers, and bring them into the Hatti-Land; then put into their hand the distaff and mirror of a woman and clothe them as women.. $.2^{22}$

Continuing this trope, a soldier's oath includes in a curse section, as a preemptive warning against any soldiers that may be tempted to break their oaths, the following dire punishment:

Let these oaths change him from a man into a woman! Let them change his troops into women, let them dress in the fashion of women and cover their heads with a length of cloth! Let them break the bows, arrows, and clubs in their hands and [let them put] in their hands the distaff and mirror! ${ }^{23}$

Such imagery is not limited to treaty texts, but I focus here on these two examples. ${ }^{24}$ In each, masculinity is paired to symbols of martial strength, which, when forcibly taken away, move the oath-breaker into the feminine category. This is further reinforced by forcing upon him the distaff and mirror, direct markers of femininity.

Returning to Mesopotamia, we see this imagery reappear in royal inscriptions of the Neo-Assyrian kings. These examples feature, like the earlier Hittite texts, the full range of embedded martial references. The imagery is employed as a curse against disobedience in the closing section of a treaty between the Assyrian king Aššur-nerari V (755-745 BCE) and Mati'-ilu, the king of Arpad. Though the first section of the treaty is lost, the remainder depicts a number of curses that will visit Mati'-ilu should he violate the oaths that the treaty requires of him, including a unique and extended metaphor where the ruler is substituted with a lamb, that will be ritually slain in his stead in the event of his betrayal. Near the end of the treaty, the following section appears:

If Mati'-ilu sins against this treaty with Aššur-nerari V, king of Assyria, may Mati'-ilu become a prostitute (munusharimtu), his soldiers women (MUNUS.MEš), may they receive [a gift] in the square of their cities like any prostitute, may one country push them to the next; may Mati'ilu's (sex) life be that of a mule, his wives extremely old; may Ištar, the goddess of

22 CTH 716; see Hillers 1964: 66; Sommer 1921. On the use of the spindle and distaff as symbols of femininity, particularly within incantations, see Hoffner 1966 and Yakar and Taffet 2007. The taking away of femininity and reinforcing or providing of masculinity appears elsewhere within Hittite rituals, principally in a text known as Paskuwatti's ritual (CTH 406); Miller 2010; Hoffner 1987.

23 See KBo VI: 34 and duplicate KUB VII: 59, edited in Oettinger 1976.

24 Mark Weeden (2013: 83-85) presents another example of this trope in his discussion of the text called the "Siege of Uršu" (KBo $1.11 \mathrm{rev}$ ). Though written in Akkadian, it centers on the military endeavors of the Hittite ruler and includes passages written in Hittite, pointing to the original Hittite context of the text. Though difficult to translate, Weeden renders lines 16-18 as follows: "A spindle they brought, the reeds (=arrows) they took away, a hair-clasp they brought, the mace they took away, last year Tudhaliya acted effeminate, now you have acted effeminate." 
men, the lady of women, take away their bow, bring them to shame and make them bitterly weep: "Woe, we have sinned against the treaty of Aššur-nerari V, king of Assyria." ${ }^{25}$

This curse section represents an attack from both sides: it targets not only Mati' ilu and his soldiers' martial abilities, with the threat to take away their bow, but also strikes at Mati'ilu's sexual potency. It compares him directly to a mule, thus declaring him to be impotent, and also states that not only will his soldiers become women, but their king will become a harimtu, or prostitute. ${ }^{26}$ In doing so, Mati' ilu will not only be transformed into a woman, but be placed even further down the social scale, with less control and personal agency. Ištar, however, is only personally responsible for taking away the weapons and martial power from him and his troops.

This imagery resurfaces in two royal inscriptions belonging to the NeoAssyrian king Esarhaddon (681-669 BCE). The first instance, in his Succession treaty, cites the following fate that shall meet those who would transgress the strictures of the treaty:

DIĜIR.MEŠ ma-la ina tupp-pi a-de-[e] an-ni-e MU-šsu-nu zak-[ru] ki-i ašs pi-laq-qi lu-šáa-as-bi$r u-k u-n u$ ki-i $\mathrm{MI}_{2}$ ina $\mathrm{IGI}_{\mathrm{LU}} \cdot \mathrm{KUR}_{2}-k u-n u$ le-pa-šu-ku-nu

May all the gods who are called by name in this treaty tablet spin you around like a spindlewhorl, may they make you like a woman before your enemy. ${ }^{27}$

As the spindle-whorl (along with the distaff and mirror, as seen in Hittite texts) is one of the objects closely associated with and a marker of femininity, its place in this text reinforces the transformation into women, and the subsequent loss of standing that implies. A stele of Esarhaddon from Zinçirli underscores these themes:

${ }^{\mathrm{d}} \mathrm{INANA}_{\text {be-let }} \mathrm{MURUB}_{4} u \mathrm{ME}_{3} z i k$-ru-su sin-niš-a-niš lu-šá-lik- $\left.m a\right\urcorner$ ina $\mathrm{KI} \cdot \mathrm{TA} \mathrm{LU}_{2} \cdot \mathrm{KUR}_{2}$-šú lu-šešib-šú ka-meš

... may the goddess Ištar, lady of war and battle, change him from a man into a woman, and may she seat him, bound, at the feet of his enemy. ${ }^{28}$

25 Parpola and Watanabe 1988: 002: v 9-15.

26 There has been some debate regarding the translation of harimtu as prostitute. Julia Assante argued for its reinterpretation as a single woman, who operates free of direct male authority, rather than a prostitute (1998). Jerrold S. Cooper more recently presented the case for its translation once again as prostitute (2016a: 211-212). In this text, prostitute seems the most likely translation, given that the imagery is placed to insult Mati'ilu and imply the loss of both his sexual potency and agency.

27 Parpola and Watanabe 1988: 006: $\$ 91$.

28 Leichty 2011: Esarhaddon 098: r. 55-56. 
As was the case with the treaty of Aššur-nerari V and Mati'-ilu, here Ištar is once again the direct cause of the emasculation that awaits any oath-breakers. This curse is also couched in military terms. Not only is Ištar's position as the goddess of war highlighted, but she renders the individual doubly powerless, first turning him into a woman and then binding him, restricting even further any potential ability he might have had. Like the practice of armpitting in ancient Greece, whereby a corpse was specifically mutilated to hobble its ghost, this threat is designed to remove all agency from those it targets. ${ }^{29}$

Though these examples are most prominent in the first millennium BCE, the Mesopotamian examples have deeper historical roots, ones shared with the Hittite texts that include similar threats of enforced femininity. Indeed, the categories of masculinity and femininity, their means of definition and identifying markers and symbols, and the threat implied in their transgressive violation all have older foundations. The Sumerian Old Babylonian, or early second millennium BCE, literary text the Hymn to Hendursaĝa describes the actions of seven figures, alternatively watchmen, bestial figures, or demonic antagonists, who, when rooted firmly in their demonic qualities, disrupt the natural order of the world through the following actions:

Hymn to Hendursầa, 85-89:

imin-be-ne diĝir munus nu-me-eš $\mathrm{u}_{3}$ nita $_{2}$ nu-mu-eš nita $a_{2}$-ra ša mu-un-du $u_{3}$-ne munus-ra $a_{2}$ mu-un-la - -ne munus-ra sišstukul da-ga? mu-ni-ib-ĝa $a_{2}-\hat{g} a_{2}-n e$

These seven, they are neither female divinities nor male divinities, They bind men; they bind the arms of women, They set the weapon at the side for women. ${ }^{30}$

The first line of this section reiterates language that is closely associated with demonic figures, who are often agendered and without familial connections of any kind. The third line of this passage, though somewhat obscure, references an action that is repeated throughout birth incantations, where a weapon

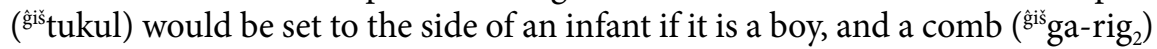
if it is a girl. ${ }^{31}$ The Hittite examples discussed previously echoed this threat by placing both the distaff and mirror at the side of warriors in order to emasculate them, but this text provides a rare example of the opposite scenario. Here, masculinity is enforced upon a woman, and although this does not appear to carry the same negative connotations as the inverse, it is still a violation of the established order and a chaotic, transgressive act. Both circumstances are

29 On the admittedly rare references to armpitting, or the specific mutilation of a corpse (maschalismos) in ancient Greece, see Ogden 2009: 162.

30 See Edzard and Wilcke 1976 for the edition of this text.

31 See Van Dijk 1975; Hoffner 1966. 
also seen in another Old Babylonian text, one centered on the goddess Ištar. This text blurs gender boundaries throughout, describing how, through Ištar "a man is like a woman, a maiden is a young man." ${ }^{32}$ Furthermore, both men and women are also described as carrying the signifiers of the other gender; men with, at different points, spindles, combs, or hairpins; while the women carry bows, slings, and sling-stones. ${ }^{33}$

The curses in treaty texts also draw upon a fear of lost male sexual potency, a fear that is widespread in Mesopotamia, if one considers the range of incantations used to address such concerns. A similar landscape of imagery is used within these medical incantations. Identified by their incipit as ša ${ }_{3}$-zi-ga or $n \bar{\imath} \check{s}$ libbi - literally, "to raise the heart" - they addressed the issue of impotence. In several of them, the afflicted man is the victim of witchcraft and consequently loses his vital force and is rendered impotent. ${ }^{34}$ In his impotent state, he is directly referred to as a woman (munus gin ${ }_{7}$ ), as one of the key markers of his own masculine power has been rendered useless. It is no coincidence that his predicament comes at the hands of a witch. While she is a symbol of liminal, possessing a chaotic and even demonic power, it is a power that is also distinctly coded as feminine.

This fear - the loss of vitality, affliction of impotence, and even disappearance or shrinking of the genitals entirely - is well represented cross-culturally and in many different historical periods, such as, for example, as seen in a psychiatric disorder known as Koro syndrome, or genital retraction syndrome. ${ }^{35}$ Accusations of overwhelmingly female witches inflicting similar afflictions, termed 'penis theft,' populate the 1487 CE witchcraft treatise, the Malleus Maleficarum, but they have far from relegated solely to the past. ${ }^{36}$ In the 1990 s and early 2000s, a similar social anxiety in West Africa led to mob-like accusations of both witchcraft in general and 'penis theft' in particular, and also tragically to the vigilante killings of accused witches. ${ }^{37}$

32 Streck and Wasserman 2018: col. i, 45.

33 Streck and Wasserman 2018: 19-20. See especially col. ii, 7, 9, and 18-19 (men); and col. ii, 8 (women).

34 STT 280.1.22-25. See Biggs 1967.

35 An individual afflicted with Koro syndrome generally believes that his genitals are suddenly and considerably diminished in size, to the point of inciting a fear that they might disappear entirely. For an overview, see Crozier 2012.

36 This phenomenon is detailed in Smith 2002: 88, who quotes several accounts of penis theft by witches. The Malleus Maleficarum (Mackay 2009) discusses the mechanism behind this sorcery in one section: "Question Nine: Whether sorceresses work on male members through the illusion of conjuring as if these limbs were completely pulled out of the body" (194-201) and a further section entitled "The way in which they take away male members" (323-330). The latter opens with the following story: "In the town of Ravensburg a certain young man was attached to a young woman, and when he wished to set her aside, he lost his male member, clearly through the art of conjuring, with the result that he could not see or feel his body as anything but smooth" (323).

37 For more recent 'outbreaks' of Koro syndrome and the accusations of witchcraft that followed, see Dzokoto and Adams 2005. 


\section{Literary Texts and Vectors of Change}

Royal inscriptions are not the only genre wherein we see enforced shifts of gender. Such changes also appear in several literary texts, though employed to distinctly different ends. Royal inscriptions, as we have seen, feature enforced femininity as a threat, a warning as to what horrors can and will visit one who breaks the terms of a treaty or oath. Literary texts include such acts in a more straightforward and descriptive role: they illustrate the power of the deity who can bring about such changes or serve a particular narrative function.

Inana/Ištar serves as the locus for such references in literary texts. In the following two examples, we see that both references to the ability to either enforce feminine qualities upon men or to swap feminine and masculine qualities entirely serve to reinforce her own abilities. The more extensive reference appears in the latter half of the Akkadian text Erra and Išum, and cites Ištar's particular abilities:

Erra and Išum, IV 52-68:

$\check{s} a$ UNUG $^{\mathrm{ki}} \check{\text { šu-bat }}{ }^{\mathrm{d} a-n i m} u \mathrm{~d} i \check{s}$-tar URU ke-ez-re-e-[ti] šam-ha-a-túu ù ha-ri-ma-[ti]

šá ${ }^{\mathrm{i} i s ̌-t a r} m u$-ta $i$-țe-ru-ši-na-ti-ma im-nu-u qa-tuš-š[ [un]

su-ti-i su-ta-a-tú na-du-u ia-ru-ra-t[i]

de-ku-ú é-an-na kur-gar-ri ${ }^{\mathrm{lu2} i-s i n-[n i]}$

šá ana šup-lu-uh $\mathrm{UG}^{3}{ }^{\mathrm{d}}$ INNIN zik-ru-su-nu ú-te-ru ana MU[NUs]

na-áš pat-ri na-áš nag-la-bi qup-pe-e u șur-t $[i]$

šá ana ul-lu-uṣ kab-ta-at ${ }^{\mathrm{d}} \mathrm{INNIN} i$-tak-ka-lu $\ulcorner a\urcorner$-[sak-ka]

As for Uruk, the dwelling of Anu and Ištar, the city of cult prostitutes, courtesans, and temple prostitutes,

Whom Ištar kept from having husbands and put under [their] own authority -

Sutean men and women emitted a clamor.

They drove (away) the cultic performers and cultic offici[als],

Whose masculinity Inana changed into femin[inity] to induce awe in the people,

As well as the bearers of swords and bearers of razors, knives, and flint [s],

Who, to make Inana joyful, continually broke t[aboos]..$^{38}$

Here, Ištar's abilities are not intended as a punishment, but a clear demonstration of her power. More oblique references to this ability occur in the Sumerian text of Enki and the World Order, where the god Enki, in a fragmentary section near the text's end, comments on how the goddess changed the left and right sides, echoing the language of determining gender in birth incantations. ${ }^{39}$

38 Cagni 1969.

39 The ETCSL edition of this text lists this line as 431: "I made you exchange its right side and its left side" (zag zid-da-bi zag gab ${ }_{2}-$ bu- $^{\ulcorner} \mathrm{bi}^{\urcorner}$šu bal he $_{2}$-ba-e-ni-`ak`-[ak]). The full edition of this text is found in Benito 1969: $77 \mathrm{ff}$. 
The above references reinforce the position of Ištar/Inana as the agent of such changes. She is directly cited in this role in most of the curse sections of treaties to include such punishments, including the stele of Esarhaddon at Zinçirli. Even though the treaty between Aššur-nerari $V$ and Mati'ilu does not specify a particular agent for Mati' ilu's change into a munusharimtu and his soldiers forced change into women, Ištar is immediately referenced following this section of the text, and explicitly cited as removing their weapons and bringing them both shame and sorrow. Forced physical changes are a hallmark of Ištar, particularly when the goddess is angered. Transformative fates found several of her past lovers, as recounted by Gilgamesh in his eponymous Akkadian epic, she turns one of her lovers, a shepherd, into a wolf for his own sheepdogs to hound, and another into a dwarf-like creature (dallalu).$^{40}$ Both are carefully crafted punishments that nevertheless require physical transformations, which were fairly rare occurrences in Mesopotamian texts. In other instances of denied masculinity, the afflicted are the victims of witchcraft, their unfortunate fate the work of another powerful but ultimately border-crossing, chaotic, and somewhat liminal figure.

It is primarily through these vectors - be they demonic or divine - that we see individuals stripped of strength and martial agency through masculine-coded insults. In the ancient Near East, a liminal and ultimately superhuman being is required to serve as the agent of such imposed change and subsequent loss of personal agency that it entails. Given that such changes are targeted attacks on markers of masculinity, it is perhaps unsurprising that these agents or vectors of change are feminine. Though demons are typically depicted as non-gendered beings, described specifically as neither male nor female, the witch is an intrinsically female figure, and the shape of her power and the threat she poses is tied to that feminine nature. ${ }^{41}$ The witch in Mesopotamia may not be the individually named and personified female figure seen in Greco-Roman representations - such as Circe, Medea, and Helen - but her power has a similar shape..$^{42}$ As strength expressed through straightforward military actions and martial ability is coded as masculine, and thus to a degree restricted from the witch, she assumes her power through her position of liminality. Ištar, of course, occupies a more difficult position - undeniably a feminine figure, martial conflict nevertheless falls under her direct dominion as a goddess, but her liminal qualities allow her to circumvent such restrictions.

40 As recounted in Epic of Gilgamesh Tablet VI: 58-79; see George 2003: 622-623; this transformation is accomplished via the Akkadian verb târu.

41 There is a large body of literature on the nature of the witch in Mesopotamia; most recently see Van Buylaere 2019 with regard to the relationship between the position of the witch and the standing of women in Mesopotamia, and cited literature. On the witch's nature in Mesopotamia see Abusch 1989 and 2007, as well the extensive study of the witch and witchcraft in Schwemer 2007: 69 ff., with recent summary in Schwemer 2019: 41-63.

42 For an overview of the witch in Greco-Roman texts, see Spaeth 2014. 


\section{Becoming a Man: When Women Move into Masculine Categories}

Shifting expressions of gender in Mesopotamia overwhelmingly conform to the categories demonstrated by the examples discussed so far. Namely, they represent lost masculinity or imposed femininity positioned as either an insult or the result of a curse. It is possible, however, to observe a shift in the other direction, whereby a woman may be treated as a man or referred to with masculine qualities and attributes. Unlike enforced femininity, which always carries with it negative connotations, and functions as insult and threat in equal measure, the examples we see of shifting from feminine to masculine categories carry no such negative connotations. Indeed, it implies a greater range of personal agency and freedom, and is normally employed only as a measure of last resort, when all other options are exhausted.

We encounter this different landscape of masculinity and femininity in legal texts, specifically concerning adoption and inheritance. The most prominent example hails not from the Mesopotamian heartland but its western periphery, from the site of Emar in the latter half of the second millennium BCE. In this text (AuOr 5-T 13), the man Ahu-țāb names his daughter, Alnašuwa, as his heir. ${ }^{43} \mathrm{He}$ states his reasons for this unconventional act quite clearly: "I have no son, [thus] I have made Alnašuwa, my daughter both male and female (NITA $\dot{u}$ MUNUS). She shall invoke my gods and my dead. I have given her my house and all my possessions." ${ }^{44}$ Alnašuwa has been co-opted as her father's heir as a matter of last resort - Ahu-țāb has no other suitable relatives or descendants of the tier required for direct inheritance, and so he ties his line of inheritance and lineage to Alnašuwa by treating her as both his son and daughter. Once she marries, her spouse could be slotted into the position of son she occupies, and another text does indeed lay out the terms by which Ahu-țāb would adopt Alnašuwa's prospective spouse, Bașșu, as his own son. ${ }^{45}$ Even beyond the caveat of her prospective spouse's status, Alnašuwa does not quite seem to acquire all the responsibilities of a man: Ahu-tāb also states that any future sons of Alnašuwa, once she is married, will be recognized as his own sons, and required to "carry a

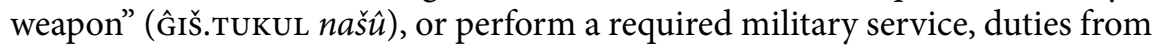
which Alnašuwa, despite her new designation of 'son', was clearly exempt. The conditions by which Alnašuwa could be recognized as both son and daughter appear to be twofold: first, Ahu-țāb must have lacked any natural male sons to serve as his heirs, and second, his daughter must have been unmarried. Even a son by marriage, it seems, would have been enough otherwise.

43 This and other texts, particularly adoption and inheritance texts that feature unusual gender assignations, are discussed in Yamada 2014.

44 Arnaud 1987: 233.

45 Arnaud 1987: 234. 
These shifting boundaries of gender are thus products of dire necessity. To invoke the Norse material once again, there is a revealingly similar phenomenon at work when women were owed wergild, or the compensation required to the living relatives of a slain individual. If the slain man had no son, brother, or father, but he did have a daughter, texts dictate she was owed the wergild like a son (sem sonr), a circumstance that once again changed if she was married. An unmarried daughter could, in a pinch and as a last resort, be considered and treated as a son. ${ }^{46}$ As Clover states: "So compelling is the principle of patrilineage that, in the event of genealogical crisis, even a woman can be conscripted as a kind of pinch hitter. Better a son who is your daughter than no son at all." ${ }^{47}$ In the text from Emar, Alnašuwa slots neatly into this role left vacant by extraordinary circumstances and a lack of other options. Similarly, Middle Assyrian laws detail how an unmarried or widowed woman may, in the absence of male relatives or descendants, demonstrate greater rights to inheritance than she otherwise would in the presence of surviving male figures. ${ }^{48}$

We see another reversal of gendered power dynamics in a late Old Babylonian text, similarly rooted in a more legalistic and contractual nature. The text documents the receipt of silver for the performance of $i l k u$ labor that had been outsourced to members of the extended family. ${ }^{49}$ It further details how three male individuals - the "sons of Nanna-mansum" - were hired out for one year by two women, both daughters-in-law to Nanna-mansum. Essentially, the two women hired their brothers-in-law to perform an ilku-duty, and one that was specifically referenced as their responsibility, not their husbands'. The contract, frustratingly, provides less information about all parties involved, and their husbands' status is unclear. While both women demonstrate a degree of autonomy that is normally exercised by either unmarried women or widows, the text stresses their status as "daughters-in-law" and their connection to their brothers-in-law. It functions as a more subtle expression of the ways in which women could and did operate in the male sphere.

46 This situation is described in the Grágás, a collection of laws from Viking age Iceland; see Dennis, Foote, and Perkins 1980 and discussion in Clover 1993: 369.

47 Clover 1993: 370.

48 In particular, see Middle Assyrian laws $A \S 33$ and $A \$ 36$ (Roth 1997). On law and legal codes in the Middle Assyrian period, see Lafont: 2003. Stol (2016: 672-673) discusses in particular the place of women in the Middle Assyrian law code in regard to inheritance.

49 Richardson 2012. 


\section{Conclusion: Gender and Autonomy}

The texts discussed in the preceding section provide critical examples of how gender could shift in practice, as well as in theory. It is clear, however, that the only such changes to occur outside of royal inscriptions and literary texts move in the positive - which is to say, male - direction, shifting a woman into the category occupied by and belonging to men. Such a change is accompanied by a corresponding increase in autonomy, at least as dictated by the same texts which moved her gender category in the first place. It is telling that any negative shifts or loss of masculinity are not actualized, as if the reality of such a threat would be too terrible to bear. ${ }^{50}$ These threats of lost masculinity and imposed femininity are thus limited primarily to the sphere of literature and royal inscriptions, appearing in texts from both Assyrian and Hittite contexts. They were employed with particular verve in treaty texts, serving as the dire punishment for the breaking of sworn oaths. Several aspects of these texts are coded to deliver the greatest punishment: here, enforced femininity bars one from participating further in the martial sphere, an area that is the dominion of Ištar, who serves as the source of these forcible shifts in gender. The goddess is herself a figure that is not easily contained within any categories, including gender, and the examples of shifts in gender limited to literary texts echo this aspect of her nature.

These examples provide an initial investigation into the landscape of shifting gender and the language of threats associated with it. Being a man connoted a greater degree of power and personal autonomy, and that freedom thus became linked to the expression of masculine traits, particularly within a martial setting. The removal, particularly through divine interference, of those martial and masculine abilities was thus coupled with the loss of that greater personal autonomy. To 'become a woman', in Mesopotamian terms, was to be forced out of the sphere of activities and personal freedoms that men enjoyed. These threats necessitated a divine, or at the least, supernatural vector, but a woman could, under extreme and very specific circumstances, transition into the male sphere and 'become a man', though without the need for such external agents. The removal of autonomy and power, or of masculinity, may have required the supernatural, but the acquisition of masculinity appears only as the product of circumstance and the confluence of unlikely though entirely possible events.

50 We do see one of the Middle Assyrian laws (A\$20) describe the punishment for homosexual activity between men as forcible castration, which would clearly remove one from the sphere of masculine autonomy. The punishment for spreading unsubstantiated rumors about other committing such activity (A@ 19) is to have one's hair forcibly cut off. Within Mesopotamia, hair is another sign of masculinity, albeit one that may eventually be recovered; Roth 1997. 


\section{Bibliography}

Abusch, T. 1989. The Demonic Nature of the Witch in Standard Babylonian Literature: the Reworking of Popular Conceptions by Learned Exorcists, in Neusner, J., Frerichs E.S., and Flesher, P.V.M. (eds.), Religion, Science, and Magic in Concert and Conflict. Oxford, pp. 27-58.

Abusch, T. 2007. Witchcraft Literature in Mesopotamia, in Leick, G. (ed.), The Babylonian World. London, pp. 373-385.

Arnaud, D. 1987. La Syrie du moyen-Euphrate sours le protectorat hitite: contrats de droit privé. AuOr 5/2, pp. 211-241.

Asher-Greve, J.M. 1997. The Essential Body: Mesopotamian Conceptions of the Gendered Body. Gender \& History 9/3, pp. 432-461.

Assante, J. 1998. The kar.kid/harimtu, Prostitute or Single Woman?: A Reconsideration of the Evidence. UF 30, pp. 5-96.

Benito, C.A. 1969. "Enki and Ninmah" and "Enki and the World Order," PhD dissertation, Philadelphia.

Bergmann, C.D. 2008. "We Have Seen the Enemy, and He is Only a She": The Portrayal of Warriors as Women, in Kelle, B.E., and Ames, F.R. (eds.), Writing and Reading War: Rhetoric, Gender, and Ethics in Biblical and Modern Contexts. Atlanta, pp. 129-142.

Biggs, R.D. 1967. ŠÀ.ZI.GA. Ancient Mesopotamia Potency Incantations. New York.

Blok, J. 2002. Women in Herodotus's Histories, in Bakker, E.J., de Jong, I.J.F., and Van Wees, H. (eds.), Brill's Companion to Herodotus. Leiden, pp. 225-243.

Bowie, A.M. (eds.) 2007. Herodotus: Histories Book VIII. Cambridge Greek and Latin Classics X. Cambridge.

Butler, J. 1988. Performative Acts and Gender Constitution: An Essay in Phenomenology and Feminist Theory. Theatre Journal 40/4, pp. 519-531.

Butler, J. 1999. Gender Trouble: Feminism and the Subversion of Identity. New York.

Cagni, L. 1969. L'epopea di Erra. Rome.

Chapman, C. 2018. The Gendered Language of Warfare in the Israelite-Assyrian Encounter. Harvard Semitic Monographs 62. Leiden.

Clover, C.J. 1993. Regardless of Sex: Men, Woman, and Power in Early Northern Europe. Speculum 36/2, pp. 363-387.

Cooper, J.S. 2016. Female Trouble and Troubled Males: Roiled Sea, Decadent Royals, and Mesopotamian Masculinities in Myth and Practice, in Zsolnay, I. (ed.), Being a Man: Negotiating Ancient Constructs of Masculinity. London, pp. 113-124.

Cooper, J.S. 2016a. The Job of Sex: the Social and Economic Role of Prostitutes in Ancient Mesopotamia, in Lion, B. and Michel, C. (eds.), The Role of Women in Work and Society in the Ancient Near East. Studies in Ancient Near Eastern Records 13. Berlin, pp. 209-227.

Couto-Ferreira, M.E. 2017. From Head to Toe: Listing the Body in Cuneiform Texts, in Wee, J.Z. (ed.), The Comparable Body - Analogy and Metaphor in Ancient Mesopotamian, Egyptian, and Greco-Roman Medicine. Studies in Ancient Medicine 49. Leiden, pp. 43-71.

Crozier, I. 2012. Making up Koro: Multiplicity, Psychiatry, Culture, and Penis-Shrinking Anxieties. Journal of the History of Medicine and Allied Sciences 67/1, pp. 36-70.

Dennis, A, Foote, P., and Perkins, R. (trans). 1980. Laws of Early Iceland, Grágás: the Codex Regis of Grágás with Material from Other Manuscripts. Winnipeg.

Dzokoto, V.A. and Adams, G. 2005. Understanding Genital-Shrinking Epidemics in West Africa: Koro, Juju, or Mass Psychogenic Illness? Culture, Medicine, and Psychiatry 29, pp. 53-78.

Edzard, D.O. and Wilcke, C. 1976. Die [H] endursanga-Hymne, in Eichler, B.L., Heimerdinger, J.W., and Sjöberg, Å.W. (eds.), Kramer Anniversary Volume: Cuneiform Studies in Honor of Samuel Noah Kramer. Alter Orient und Altes Testament 25. Neukirchen-Vluyn, pp. 139-176.

Friðriksdóttir, J. K. 2013. Women in Old Norse Literature: Bodies, Words, and Power. New York.

Gardeła, L. 2013. "Warrior-women" in Viking Age Scandinavia? A Preliminary Archaeological Study. Analecta Archaeologica Ressoviensia, 8, pp. 273-339

George, A.R. 2003. The Babylonian Gilgamesh Epic: Introduction, Critical Edition, and Cuneiform Texts. Oxford. 
George, A.R. 2013. The Poem of Erra and Ishum: A Babylonian Poet's View of War, in Kennedy, H. (ed.), Warfare and Poetry in the Middle East. London, pp. 39-71.

Grayson, A.K. 1987. Assyrian Rulers of the Third and Second Millennium BC (to 1115 BC). The Royal Inscriptions of Mesopotamia. Assyrian Periods 1. Toronto.

Hillers, D.R. 1964. Treaty Curses and the Old Testament Prophets. Biblica et Orientalia 16. Rome.

Hoffner, H.A. 1966. Symbols for Masculinity and Femininity: their Use in Ancient Near Eastern Sympathetic Magic Rituals. JBL 85, pp. 326-334.

Hoffner, H.A. 1987. Paškuwatti’s Ritual against Sexual Impotence (CTH 406). AuOr 5, pp. 271-287.

Jochens, J. 1996. Old Norse Images of Women. Philadelphia.

Lafont, S. 2003. Mesopotamia: Middle Assyrian Period, in Westbrook, R. (ed.), A History of Ancient Near Eastern Law. Handbook of Oriental Studies 72. Leiden, pp. 521-563.

Leichty, E. 2011. The Royal Inscriptions of Esarhaddon, King of Assyria (680-669 BC). The Royal Inscriptions of the Neo-Assyrian Period 4.Winona Lake.

Mackay, C.S. (trans). 2009. The Hammer of Witches: A Complete Translation of the Malleus Maleficarum. New York.

Mayor, A. 2014. The Amazons: Lives and Legends of Warrior Women across the Ancient World. Princeton.

McLaughlin, M. 1990. The Woman Warrior: Gender, Warfare, and Society in Medieval Europe. Women's Studies: An Inter-Disciplinary Journal 17, pp. 193-209.

Miller, J.L. Paskuwatti's Ritual: Remedy for Impotence or an Antidote to Homosexuality? Journal of Ancient Near Eastern Religions 10/1, pp. 83-89.

Munson, R.V. 1988. Artemisia in Herodotus. Classical Antiquity 7/1, pp. 91-106.

Norrman, L. 2000. Woman or Warrior? The Construction of Gender in Old Norse Myth, in Barnes, G. and Ross, M.C. (eds.), Old Norse Myths, Literature, and Society: Proceedings of the $11^{\text {th }}$ International Saga Conference. Sydney, pp. 375-385.

Oettinger, N. 1976. Die Militärischen Eide der Hethiter. Wiesbaden.

Ogden, D. 2009. Magic, Witchcraft, and Ghosts in the Greek and Roman Worlds: A Sourcebook. Oxford.

Parpola, S. and Watanabe, K. 1988. Neo-Assyrian Treaties and Loyalty Oaths. State Archives of Assyria 2. Helsinki.

Pryke, L.M. 2017. Ishtar (Gods and Heroes of the Ancient World). New York.

Richardson, S. 2012. "The Crowns of Their bābtum": On Wives, Wards, and Witnesses. JAOS 132, pp. 623-639.

Roth, M.T. 1997. Law Collections from Mesopotamia and Asia Minor. Atlanta.

Schwemer, D. 2007. Abwehrzauber und Behexung: Studien zum Schadenzauberglauben im Alten Mesopotamien; unter Benutzung von Tzvi Abuschs kritischem Katalog und Sammlungen im Rahmen des Kooperationsprojektes Corpus of Mesopotamian Anti-Witchcraft Rituals. Wiesbaden.

Schwemer, D. 2019. Cultural Constructions of Ambiguous, Unsanctioned, or Illegitimate Ritual: Mesopotamia, in Frankfurter, D. (ed.), Guide to the Study of Ancient Magic. Leiden, pp. 36-64.

Self, K.M. 2014. The Valkyrie's Gender: Old Norse Shield-Maidens and Valkyries as a Third Gender. Feminist Formations 26/1, pp. 143-172.

Smith, M. 2002. The Flying Phallus and the Laughing Inquisitor: Penis Theft in the "Malleus Maleficarum." Journal of Folklore Research 39/1, pp. 85-117.

Sommer, F. 1921. Ein hethitisches Gebet. ZA 33, pp. 85-102.

Sørensen, P.M. 1983. The Unmanly Man: Concepts of Sexual Defamation in Early Northern Society. Odense.

Spaeth, B.S. 2014. From Goddess to Hag: the Greek and Roman Witch in Classical Literature, in Stratton, K.B. and Kalleres, D.S. (eds.), Daughters of Hecate: Women and Magic in the Ancient World. Oxford, pp. 41-70.

Stol, M. 2016. Women in the Ancient Near East. Berlin.

Streck, M.P. and Wasserman, N. 2018. The Man is Like a Woman, the Maiden is a Young Man: A new edition of Ištar-Louvre (Tab. I-II). OrNS 87/1, pp. 1-38.

Svärd, S. and Grace-Ventura, A. (eds.) 2018. Studying Gender in the Ancient Near East. Winona Lake. 
Turco, J. 2016. Gender, Violence, and the 'Enigma' of Gísla Saga. The Journal of English and Germanic Philology 115/3, pp. 277-298.

Van Buylaere, G. 2019. The Decline of Female Professionals - and the Rise of the Witch - in the Second and Early First Millennium BCE. Magic, Ritual, \& Witchcraft 14/1, pp. 37-61.

Van Dijk, J. 1975. Incantations accompagnant la naissance de l'homme. OrNS 44/1, pp. 52-79.

Waterfield, R. (trans.) 1998. Herodotus: the Histories. Oxford.

Weeden, M. 2013. Poetry and War among the Hittites, in Kennedy, H. (ed.), Warfare and Poetry in the Middle East. London, pp. 73-97.

Westenholz, J.G. and Zsolnay, I. 2016. Categorizing Men and Masculinity in Sumer, in Zsolnay, I. (ed.), Being a Man: Negotiating Ancient Constructs of Masculinity. London, pp. 21-41.

Yakar, J. and Taffet, A. 2007. The Spiritual Connotations of the Spindle and Spinning: Selected Cases from Ancient Anatolia and Neighboring Lands, in Alparslan, M., Doğan-Alparslan, M., and Peker, H. (eds.), VITA: Festschrift in Honor of Belkıs Dinçol and Ali Dinçol. Istanbul: pp. 781-788.

Yamada, M. 2014. The Women Designated 'Man and Woman' in Emar and Ekalte. Paper presented at the REFEMA $4^{\text {th }}$ Workshop, Tokyo, June 2014. Published on REFEMA.hypotheses.org. https:// refema.hypotheses.org/1142 (accessed March 12, 2019).

Zsolnay, I. 2010. Ištar, 'Goddess of War, Pacifier of Kings': An Analysis of Ištar's Martial Role in the Maledictory Sections of the Assyrian Royal Inscriptions, in Kogan, L. (ed.), Language in the Ancient Near East: Proceedings of the 53e Rencontre Assyriologique Internationale. Winona Lake, pp. 389-402. 